VOL. 3 NO. 2 (2020) : 87-93

\title{
ANALISIS KEMAMPUAN KONEKSI MATEMATIS MATERI SISTEM PERSAMAAN LINEAR DUA VARIABEL DITINJAU DARI KONEKSI REPRESENTASI DAN KONEKSI PROSEDURAL
}

\author{
Siti Dwi Ifa Rochmawati ${ }^{1}$, Junarti ${ }^{2}$, Ifa Khoiria Ningrum ${ }^{3}$ \\ IKIP PGRI Bojonegoro, sitidwiifarochmawati@gmail.com ${ }^{1}$ \\ IKIP PGRI Bojonegoro, junarti@ikippgribojonegoro.ac.id ${ }^{2}$ \\ IKIP PGRI Bojonegoro, nifakhoiria@gmail.com ${ }^{3}$ \\ Received : 7 Juli 2020, Revised : 7 September 2020, Accepted : 30 Oktober 2020 \\ (C) Mathematics Education Unugiri 2020
}

\begin{abstract}
This article aims to determine the extent of the mathematical connection ability of the linear equations system of two variables in terms of the connection representation and procedural connections. This type of research uses a qualitative approach. This study's subjects were the students of class X MIPA 1 MA P2K Al Hidayah Lajukidul, which numbered 24 students. However, only six subjects were taken based on the level of mathematical connection ability high, medium, and low that had been selected by mathematics subject teachers based on students' ability to solve math story problems. The research instrument consisted of tests and interview questions. Data analysis techniques using the model of Miles and Huberman include data reduction, data presentation, and concluding. The study results showed that in question no. 1, all research subjects can represent connections and procedural connections, students can write mathematical symbols and answer questions using formulas correctly. In problem no.2, only the subject of high mathematical connection ability can connect representation and procedural connections. The other subject is not quite right in writing mathematical symbols. In question no.3, only subjects with low mathematical connection ability do not have representation and procedural connection skills; students only write what is known but is incomplete. In conclusion, the two-variable linear equation system's mathematical connection ability in terms of the connection representation and procedural connections are not evenly distributed.

Keywords: Mathematical Connection Capability, Two-Variable linear Equation System, Representation Connection, Procedural Connection
\end{abstract}

\begin{abstract}
Abstrak
Artikel ini bertujuan untuk mengetahui sejauhmana kemampuan koneksi matematis materi sistem persamaan linear dua variabel ditinjau dari koneksi representasi dan koneksi prosedural. Jenis penelitian ini menggunakan pendekatan kualitatif. Subjek penelitian ini adalah siswa kelas X MIPA 1 MA P2K Al Hidayah Lajukidul yang berjumlah 24 siswa tetapi hanya diambil 6 subjek berdasarkan tingkat kemampuan koneksi matematis tinggi, sedang, dan rendah yang telah dipilih oleh guru mata pelajaran matematika berdasarkan kemampuan siswa dalam menyelesaikan soal cerita matematika. Instrumen penelitian terdiri dari soal tes dan wawancara. Teknik analisis data menggunakan model Miles dan Huberman meliputi reduksi data, penyajian data, dan penarikan kesimpulan. Hasil penelitian menunjukkan bahwa pada soal no. 1 semua subjek penelitian mempunyai kemampuan koneksi representasi dan koneksi prosedural, siswa mampu menuliskan simbol matematika dan menjawab soal menggunakan rumus dengan benar. Pada soal no.2 hanya subjek kemampuan koneksi matematis tinggi yang mempunyai kemampuan koneksi representasi dan koneksi prosedural, subjek yang lain kurang tepat dalam menuliskan simbol matematika. Pada soal no.3 hanya subjek kemampuan koneksi matematis rendah yang belum mempunyai kemampuan koneksi representasi dan prosedural, siswa hanya menuliskan apa yang diketahui tetapi tidak lengkap. Kesimpulannya kemampuan koneksi matematis materi sistem persamaan linear dua variabel ditinjau dari koneksi representasi dan koneksi prosedural belum merata.
\end{abstract}

Kata kunci: Kemampuan Koneksi Matematis, Sistem Persamaan Linear Dua Variabel, Koneksi Representasi, Koneksi Prosedural 


\section{Pendahuluan}

Matematika dipandang sebagai salah satu mata pelajaran yang dinilai cukup memegang peranan penting dalam membentuk siswa yang berkualitas. Hal ini dikarenakan matematika merupakan suatu sarana berpikir untuk mengkaji sesuatu secara logis dan sistematis, maka perlu adanya peningkatan mutu pelajaran matematika.

Menurut Rossydha [1] tujuan pembelajaran matematika dalam standar isi yang dikeluarkan oleh Badan Standar Nasional Pendidikan (BSNP) menunjukkan bahwa penguasaan matematika tidak hanya sebatas penguasaan fakta dan prosedur matematika serta pemahaman konsep, tetapi juga berupa kemampuan proses matematika siswa seperti pemecahan masalah, penalaran, komunikasi dan koneksi matematika. Semuanya harus saling menunjang dalam proses pembelajaran matematika sehingga siswa dapat menguasai matematika secara utuh. Menurut Kusuma (dalam Mandasari) [2] kemampuan koneksi matematika adalah kemampuan seseorang dalam memperlihatkan hubungan internal dan eksternal matematika, yang meliputi koneksi antar topik matematika, koneksi dengan disiplin ilmu lain, dan koneksi dengan kehidupan sehari-hari.

Kemampuan koneksi penting dimiliki oleh siswa agar mereka mampu menghubungkan antara materi yang satu dengan materi yang lainnya. Selain itu, jika siswa mampu mengaitkan materi yang mereka pelajari dengan pokok bahasan sebelumnya atau dengan mata pelajaran lain, maka pembelajaran matematika menjadi lebih bermakna. Namun kenyataanya, penelitian yang dilakukan oleh Sugiman [3] dalam sebuah SMP diperoleh bahwa tingkat kemampuan koneksi matematik siswa baru mencapai rata-rata $53,8 \%$. Capaian ini tergolong rendah. Faktor lain penyebab rendahnya kemampuan siswa dalam memahami matematika disebabkan rendahnya daya ingat siswa terhadap konsep konsep dasar matematika yang telah diajarkan [4]. Hal ini menyebebkan kemampuan koneksi mereka belum optimal.

Penelitian ini menggunakan materi Sistem Persamaan Linear Dua Variabel (SPLDV) untuk diujikan kepada subjek penelitian karena pada penelitian sebelumnya yang dilakukan oleh Rismawati dkk [5] menyatakan bahwa siswa belum mampu menggunakan kemampuan koneksi matematis dalam menyelesaian soal materi sistem persamaan linear dua variabel yang diberikan. Sistem Persamaan Linear Dua Variabel (SPLDV) merupakan suatu sistem yang terdiri atas dua persamaan linier yang mempunyai dua variabel. Dalam sebuah Sistem Persamaan Linear Dua Variabel (SPLDV) biasanya melibatkan dua persamaan dengan dua variabel. Kemampuan koneksi matematis siswa seharusnya digali agar pembelajaran berjalan sesuai harapan yaitu siswa mampu menyelesaikan soal cerita sistem persamaan linear dua variabel yang berhubungan antar konten matematika, hubungan materi sistem persamaan linear dua variabel dengan bidang lain, dan hubungan dalam kehidupan sehari-hari.

Pada jenjang pendidikan Sekolah Dasar (SD/MI) siswa sudah diajarkan soal yang berkaitan dengan koneksi. Seharusnya siswa jenjang pendidikan Sekolah Menengah Atas (SMA/MA) sudah bisa menyelesaikan soal yang berkaitan dengan koneksi matematika. Siswa diharapkan mempunyai kemampuan koneksi representasi. Suatu konsep direpresentasikan dengan cara yang berbeda seperti simbolik (aljabar), grafik (geometris), bergambar (diagram), manipulatif (objek fisik), deskripsi verbal (lisan), atau deskripsi tertulis [6]. Koneksi representasi penting dalam menyelesaikan soal cerita dan kemudian diubah menjadi grafik, tabel, teks tertulis atau simbolsimbol matematika. Selain itu, siswa juga diharapkan mempunyai kemampuan koneksi prosedural. Koneksi Ini dimanifestasikan ketika menggunakan aturan, algoritma atau formula yang ditetapkan secara default, dalam catatan semiotik, untuk sampai pada hasil deskripsinya [7]. Koneksi prosedural penting dalam menyelesaikan soal dengan menggunakan aturan rumus dengan benar dan runtut.

Beberapa penelitian terdahulu yang relevan terkait dengan koneksi matematis yang dilakukan oleh Huda [8] menyatakan bahwa adanya perbedaan kemampuan koneksi matematis siswa dan juga diperkuat dengan penelitian terdahulu yang dilakukan Anandita [9] juga menyatakan bahwa terdapat perbedaan kemampuan koneksi matematis siswa.

Berdasarkan uraian di atas, maka penelitian ini memiliki tujuan yaitu mengetahui sejauhmana kemampuan koneksi matematis materi sistem persamaan linear dua variabel ditinjau dari koneksi representasi dan koneksi prosedural.

\section{Metode Penelitian}

Jenis penelitian ini menggunakan pendekatan kualitatif. Penelitian ini dilakukan di MA P2K Al Hidayah Lajukidul. Waktu penelitian 
yaitu pada semester genap Tahun Pelajaran 2019/2020 pada tanggal 16 Maret 2020 sampai 28 Maret 2020. Subjek penelitian ini adalah siswa kelas $X$ MIPA 1 MA P2K Al Hidayah Lajukidul yang berjumlah 24 siswa tetapi hanya diambil 6 subjek berdasarkan tingkat kemampuan koneksi matematis tinggi, sedang, dan rendah yang telah dipilih oleh guru mata pelajaran matematika berdasarkan kemampuan siswa dalam menyelesaikan soal cerita matematika. Subjek terdiri dari 2 siswa dengan kemampuan koneksi matematis tinggi, 2 siswa dengan kemampuan koneksi matematis sedang, dan 2 siswa dengan kemampuan koneksi matematis rendah.

Instrumen penelitian terdiri dari soal tes dan wawancara. Soal tes berjumlah 3 butir soal yang sesuai dengan kemampuan koneksi matematis ditinjau dari koneksi representasi dan koneksi prosedural dan begitu juga dengan wawancara. Sebelum diujicobakan, instrumen telah divalidasi oleh 3 validator.

Tes digunakan untuk mengetahui kemampuan koneksi matematis materi sistem persamaan linear dua variabel ditinjau dari koneksi representasi dan koneksi prosedural. Kemudian dilakukan penginterpretasian terhadap kemampuan koneksi matematis siswa yang satu dengan siswa lainnya. Wawancara dilakukan untuk menggali pekerjaan siswa tentang kemampuan koneksi matematis materi sistem persamaan linear dua variabel ditinjau dari koneksi representasi dan koneksi prosedural. Wawancara yang dibuat adalah untuk menindak lanjuti pendalaman tentang pekerjaan siswa dalam menjawab soal tes kemampuan koneksi matematis materi sistem persamaan linear dua variabel ditinjau dari koneksi representasi dan koneksi prosedural.

Teknik analisis data menggunakan model Miles dan Huberman [10] yang terdiri dari tiga langkah yaitu reduksi data, penyajian data dan penarikan kesimpulan. Reduksi data yaitu dengan mendeskripsikan hasil pekerjaan siswa dan menginterpretasikan pola jawaban siswa. Penyajian data berupa hasil pekerjaan siswa dan hasil wawancara yang telah dipilih sebagai subjek penelitian. Adapun penarikan kesimpulan terkait tentang perbandingan hasil pekerjaan siswa dengan hasil wawancara, sehingga dapat diketahui kemampuan koneksi matematis siswa ditinjau dari koneksi representasi dan koneksi prosedural.

\section{Pembahasan}

http://journal.unugiri.ac.id/index.php?journal=JaMES
Penelitian ini dilakukan di kelas X MIPA 1 MA P2K Al Hidayah Lajukidul pada semester genap 2019/2020. Sebelum melakukan penelitian, hal yang dilakukan yaitu observasi di sekolah tersebut. Hasil dari observasinya yaitu siswa sudah diajarkan materi sistem persamaan linear dua variabel. Sehingga dilakukanlah tes untuk mengetahui kemampuan koneksi matematis ditinjau dari koneksi represenrasi dan koneksi proseduralnya. Berdasarkan soal tes yang terdiri dari 3 butir soal, koneksi representasi dan koneksi prosedual ditinjau dari beberapa aspek

Tabel 1. Soal Kemampuan Koneksi Matematis Materi Sistem Persamaan Linear Dua Variabel

\begin{tabular}{|c|c|}
\hline $\begin{array}{c}\text { Koneksi } \\
\text { Representasi dan } \\
\text { Koneksi Prosedural } \\
\text { Ditinjau Dari } \\
\text { Aspek } \\
\end{array}$ & Soal \\
\hline $\begin{array}{c}\text { Antas konten } \\
\text { matematika }\end{array}$ & $\begin{array}{l}\text { Diketahui keliling persegi } \\
\text { panjang adalah } 60 \mathrm{~cm} \text {. jika } \\
\text { lebarnya } \times \mathrm{cm} \text { dan panjangnya } \\
\text { kurang dari } 10 \mathrm{~cm} \text { dari } \\
\text { lebarnya. Tentukan luas } \\
\text { persegi panjang tersebut! }\end{array}$ \\
\hline Antar bidang lain & $\begin{array}{l}\text { Kecepatan terbang seekor } \\
\text { burung dipengaruhi oleh } \\
\text { kecepatan angin, jika arah } \\
\text { angin searah dengan arah } \\
\text { gerak burung maka kecepatan } \\
\text { terbang burung tersebut } 45 \\
\text { km/jam sebaliknya jika arah } \\
\text { angin berlawanan dengan arah } \\
\text { gerak burung maka kecepatan } \\
\text { burung tersebut } 29 \mathrm{~km} / \mathrm{jam} . \\
\text { berapa rata-rata kecepatan } \\
\text { angin? }\end{array}$ \\
\hline $\begin{array}{c}\text { Antar kehidupan } \\
\text { sehari hari }\end{array}$ & $\begin{array}{l}\text { Di dalam dompet ibu terdapat } \\
15 \text { lembar uang Rp } 10.000,00 \\
\text { dan Rp 20.000,00 untuk } \\
\text { dibelanjakan keperluan } \\
\text { bulanan. Jumlah uang ibu Rp. } \\
230.000,00 \text { berapa lembar } \\
\text { masing-masing uang ibu? }\end{array}$ \\
\hline
\end{tabular}

Setelah hasil tes didapatkan, maka diperoleh data jawaban siswa. Berikut adalah 6 subjek yang dianalisis berdasarkan kemampuan koneksi matematis siswa ditinjau dari koneksi representasi dan koneksi prosedural. Adapun pembagiannya 2 jawaban subjek kemampuan koneksi matematis pada soal nomor 1, 2 jawaban subjek kemampuan koneksi matematis pada soal nomor 2, dan 2 
jawaban subjek kemampuan koneksi matematis pada soal nomor 3 .

1. Diketahui keliling persegi panjang adalah $60 \mathrm{~cm}$. jika lebarnya x cm dan panjangnya kurang dari $10 \mathrm{~cm}$ dari lebarnya. Tentukan luas persegi panjang tersebut!

a. Jawaban No. 1 subjek kemampuan koneksi matematis tinggi 1 atau beri inisial $\mathrm{MT}_{1}$

$\mathrm{MT}_{1}$ dapat menuliskan apa yang diketahui dan apa yang ditanyakan pada soal tersebut ke dalam simbol matematika dengan benar. $\mathrm{MT}_{1}$ dapat menggunakan apa yang diketahui pada soal tersebut dengan benar untuk mencari luas persegi panjang. $\mathrm{MT}_{1}$ mencari lebar terlebih dahulu dengan memisalkan lebar sama dengan y sedangkan panjang sama dengan y-10 setelah lebar dan panjang diketahui subjek baru mencari luas persegi panjang dengan rumus yang benar.

. Hal ini terlihat bahwa $\mathrm{MT}_{1}$ memahami soal dengan baik dan sangat rinci dalam menyeseaikan soal tersebut. Hal ini dapat ditunjukkan oleh gambar 1 berikut ini:

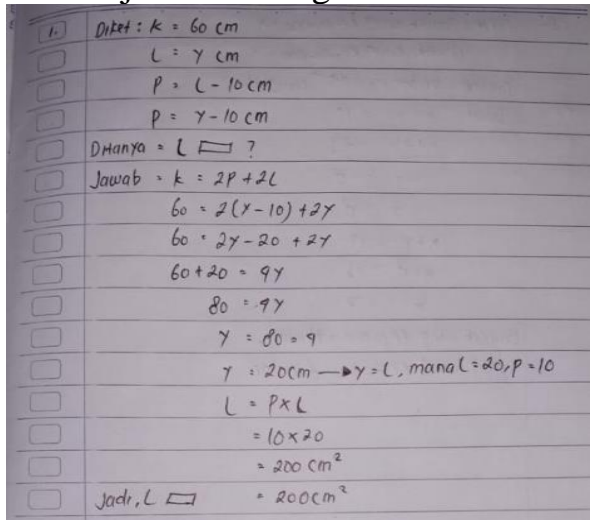

\section{Gambar 1. Hasil Kemampuan Koneksi} Matematis $\mathbf{M T}_{1}$

Berdasarkan jawaban di atas dan hasil wawancara, terlihat bahwa siswa tersebut memmpunyai kemampuan koneksi matematis karena dapat menuliskan apa yang diketahui, ditanyakan, dan jawaban ke dalam simbol matematika dengan benar. Siswa juga mampu menggunakan rumus dengan benar untuk menyelesaikan soal. Hal tersebut terlihat bahwa subjek $\mathrm{MT}_{1}$ sudah mempunyai kemampuan koneksi representasi dan koneksi prosedural dengan baik.

b. Jawaban No. 1 subjek kemampuan koneksi matematis rendah 2 atau berinisial $\mathrm{MR}_{2}$

$\mathrm{MR}_{2}$ menuliskan apa yang diketahui dan yang ditanyakan ke dalam simbol matematika dengan benar. $\mathrm{MR}_{2}$ juga menuliskan jawaban ke dalam simbol matematika dengan benar dan jawaban dikerjakan dengan menggunakan rumus atau aturan yang benar dan runtut. Terlihat bahwa $\mathrm{MR}_{2}$ sudah mengetahui simbol panjang, lebar, keliling, dan luas jika ditulis ke dalam simbol matematika. $\mathrm{MR}_{2}$ mencari lebar terlebih dahulu melalui rumus keliling, kemudian mencari luas dengan rumus luas = panjang x lebar. $\mathrm{MR}_{2}$ kurang teliti dalam nenuliskan satuan luas seharusnya luas sama dengan $200 \mathrm{~cm}^{2}$ sedangkan $\mathrm{MR}_{2}$ hanya menuliskan luas sama dengan $200 \mathrm{~cm}$.

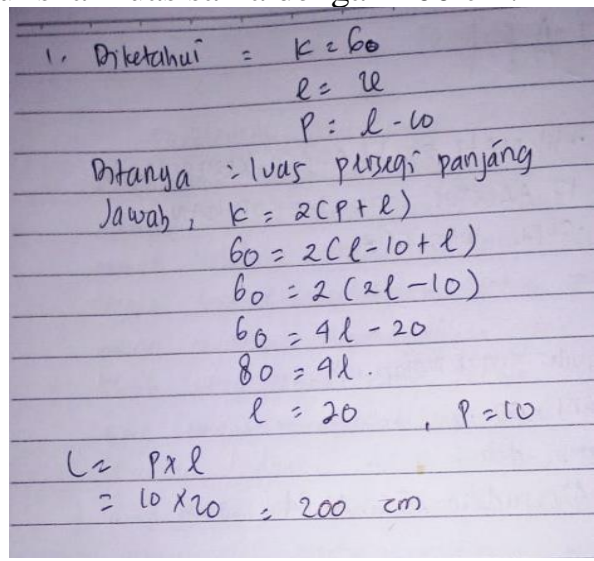

Gambar 2. Hasil Kemampuan Koneksi Matematis $\mathbf{M R}_{2}$

Berdasarkan hasil wawancara, siswa tidak menjelaskan jawaban secara rinci tetapi jawaban sudah benar hanya ada 1 simbol yang kurang benar yaitu satuan luas. Hal tersebut terlihat bahwa subjek $\mathrm{MR}_{2}$ kemampuan koneksi representasinya belum baik tetapi kemampuan koneksi proseduralnya sudah baik.

Subjek $\mathrm{MT}_{2}, \mathrm{MS}_{1}, \mathrm{MS}_{2}$, dan $\mathrm{MR}_{1}$ sudah mempunyai koneksi representasi yang baik. Hal itu terlihat subjek mampu menuliskan apa yang diketahui, ditanyakan, dan dijawab menggunakan simbol matematika dengan benar. Subjek $\mathrm{MT}_{2}, \mathrm{MS}_{1}, \mathrm{MS}_{2}$, dan $\mathrm{MR}_{1}$ juga sudah mempunyai koneksi prosedural dengan baik. Hal itu terlihat subjek mampu menuliskan jawaban dengan menggunakan aturan rumus dengan benar dan runtut.

2. Kecepatan terbang seekor burung dipengaruhi oleh kecepatan angin, jika arah angin searah dengan arah gerak burung 
maka kecepatan terbang burung tersebut 45 $\mathrm{km} / \mathrm{jam}$ sebaliknya jika arah angin berlawanan dengan arah gerak burung maka kecepatan burung tersebut $29 \mathrm{~km} / \mathrm{jam}$. berapa rata-rata kecepatan angin?

a. Jawaban No. 2 subjek kemampuan koneksi matematis sedang 2 atau beri inisial $\mathrm{MS}_{2}$

Pada soal nomor $2 \mathrm{MS}_{2}$ sudah benar menuliskan simbol kecepatan dengan $\mathrm{V}$ karena pada soal nomor 2 koneksi matematisnya terhadap fisika atau bidang lain selain matematika. Kecepatan angin dimisalkan dengan Va sedangkan kecepatan burung dimisalkan dengan Vb. Selain itu, subjek $\mathrm{MS}_{2}$ juga menggunakan metode eliminasi untuk mencari kecapatan rata-rata angin. Pada soal tersebut $\mathrm{MS}_{2}$ juga masih belum sepenuhnya mampu menuliskan apa yang diketahui ke dalam simbol matematika dengan benar karena persaman kedua tidak $\mathrm{Va}-\mathrm{Vb}=29$ tetapi $\mathrm{Vb}-\mathrm{Va}=29 . \mathrm{MS}_{2}$ salah dalam menuliskan persamaan sehingga jawaban belum benar meskipun jawaban dikerjakan dengan aturan rumus yang benar dan runtut.

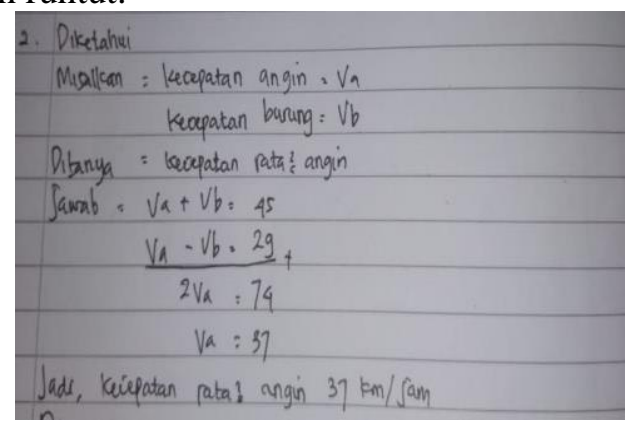

Gambar 3. Hasil Kemampuan Koneksi Matematis $\mathbf{M S}_{\mathbf{2}}$

Saat wawancara $\mathrm{MS}_{2}$ menjawab pertanyaan yang diberikan dengan lancar dan yakin. $\mathrm{MS}_{2}$ belum mengetahui jawaban yang benar. Hal tersebut terlihat bahwa subjek $\mathrm{MS}_{2}$ kemampuan koneksi representasinya belum baik tetapi kemampuan koneksi proseduralnya sudah baik.

b. Jawaban No. 2 subjek kemampuan koneksi matematis rendah 1 atau beri inisial $\mathrm{MR}_{1}$

$\mathrm{MR}_{1}$ menuliskan apa yang diketahui dengan membuat permisalan yaitu kecepatan angin $\mathrm{x}$ dan kecepatan burung $\mathrm{y}$. Namun, seharusnya kecepatan ditulis dengan simbol V. Selain itu, $M_{1}$ masih belum benar dalam menuliskan persamaan ke 2 yang seharusnya $\mathrm{y}-\mathrm{x}=29 . \mathrm{MR}_{1}$ sudah menuliskan jawaban dengan simbol matematika dan dikerjakan dengan aturan yang benar yaitu eliminas karena persamaan yang ditulis belum benar sehingga jawaban juga belum benar.

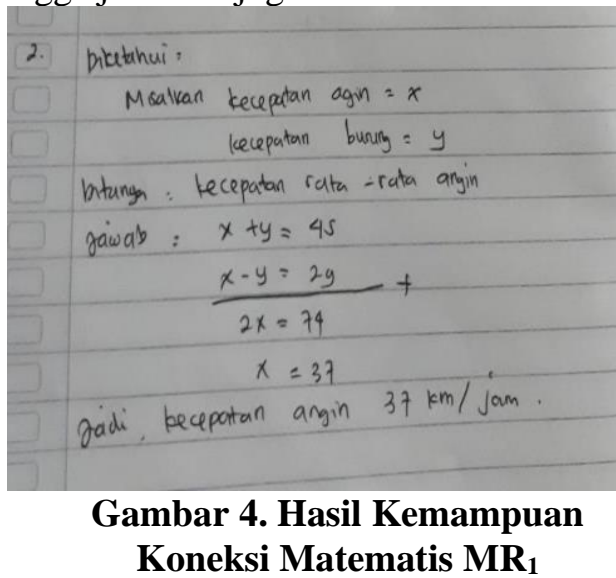

Saat wawancara terlihat bahwa $\mathrm{MR}_{1}$ belum memahami soal dengan baik dan tidak mempunyai sedikit keraguan pada jawabannya padahal jawaban $\mathrm{MR}_{1}$ belum benar dan tidak dicek lagi. $\mathrm{MR}_{1}$ belum mampu menuliskan persamaan dengan benar sehingga hasilnya salah tetapi jawaban dikerjakan menggunakan aturan rumus dengan benar dan runtut. Hal tersebut terlihat bahwa subjek $\mathrm{MR}_{1}$ kemampuan koneksi representasinya belum baik tetapi kemampuan koneksi proseduralnya sudah baik.

Subjek $\mathrm{MT}_{1}$ dari jawaban yang dianalisis sudah mempunyai koneksi representasi dan koneksi prosedural dengan baik. $\mathrm{MT}_{2}$ dan $\mathrm{MS}_{1}$ belum mempunyai koneksi representasi dengan baik karena belum menuliskan apa yang diketahui menggunakan simbol matematika dengan benar tetapi koneksi proseduralnya sudah baik karena soal diselesaikan dengan menggunakan aturan rumus dengan benar dan runtut. $\mathrm{MR}_{2}$ belum mempunyai koneksi representasi dan koneksi prosedural dengan baik karena tidak menjawab soal.

3. Di dalam dompet ibu terdapat 15 lembar uang Rp 10.000,00 dan Rp 20.000,00 untuk dibelanjakan keperluan bulanan. Jumlah uang ibu Rp. 230.000,00 berapa lembar masingmasing uang ibu?

a. Jawaban No. 3 subjek kemampuan koneksi matematis tinggi 2 atau beri inisial $\mathrm{MT}_{2}$ 
$\mathrm{MT}_{2}$ memahami soal nomor 3 karena $\mathrm{MT}_{2}$ mampu menuliskan apa yang diketahui,ditanyakan, dan jawaban ke dalam simbol matematika dengan benar dan dikerjakan dengan aturan rumus dengan benar dan runtut. Hanya saja ada yang tidak dijabarkan seperti tidak dijelaskan mengapa nilai y pada salah satu persamaan diganti dengan 8 .

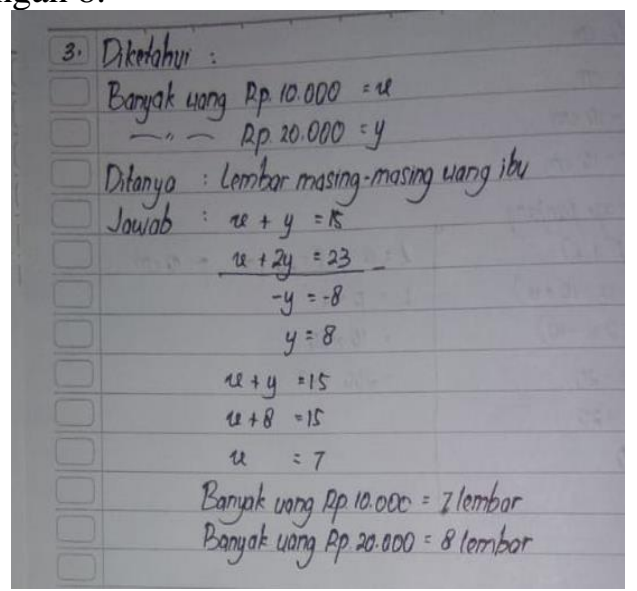

Gambar 5. Hasil Kemampuan Koneksi Matematis $\mathbf{M T}_{2}$

Wawancara berjalan dengan lancar, pada jawaban $\mathrm{MT}_{2}$ tidak menuliskan dengan runtut namun pada wawancara $\mathrm{MT}_{2}$ menjawab dengan benar dan runtut. Hal tersebut terlihat bahwa subjek $\mathrm{MT}_{2}$ kemampuan koneksi representasi dan koneksi proseduralnya sangat baik.

b. Jawaban No. 3 subjek kemampuan koneksi matematis rendah 1 atau beri inisial $\mathrm{MR}_{1}$

$\mathrm{MR}_{1}$ hanya menuliskan apa yang diketahui dan ditanyakan dengan bahasanya sendiri tidak dituliskan ke dalam simbol matematika. $\mathrm{MR}_{1}$ tidak menulis jawaban dan tidak membuat permisalan ke dalam simbol matematika.

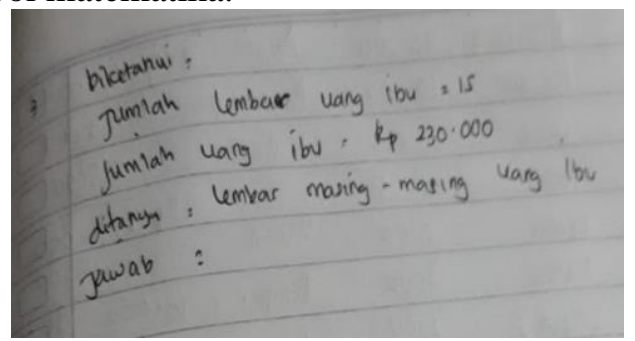

Gambar 6. Hasil Kemampuan Koneksi Matematis $\mathbf{M R}_{1}$

Saat wawancara $\mathrm{MR}_{1}$ mengaku beum memahami soal nomor 3. Hal tersebut terlihat bahwa subjek $\mathrm{MR}_{1}$ kemampuan koneksi representasi dan kemampuan koneksi proseduralnya belum baik.

MT1, MS1, dan MS2 sudah mempunyai koneksi representasi dan koneksi prosedural dengan baik. Hanya saja subjek $\mathrm{MS}_{2}$ kurang teliti pada kata jadi, banyak uang Rp 10.000 sama dengan 8 lembar dan banyak uang Rp 20.000 sama dengan 7 lembar. Jawaban tersebut belum benar seharusnya banyak uang Rp 10.000 sama dengan 7 lembar dan banyak uang Rp 20.000 sama dengan 8 lembar. $\mathrm{MR}_{2}$ hanya menuliskan satu persamaan dan soal tidak diselesaikan. Hal tersebut terlihat bahwa $\mathrm{MR}_{2}$ belum mempunyai koneksi representasi dan koneksi prosedura dengan baik.

Paparan pola jawaban di atas, yang setiap 2 jawaban subjek mewakili masingmasing butir soal. Secara keseluruhan siswa sudah dapat memahami materi sistem persamaan linear dua variabel. Kurangnya ketelitian menjadi salah satu faktor penyebab koneksi representasi siswa belum baik. Seperti pada soal no.1 terlihat subjek $\mathrm{MR}_{2}$ sudah menuliskan apa yang diketahui,ditanyakan, dan dijawab menggunakan simbol matematika. Soal juga diselesaiakan dengan menggunakan aturan rumus dengan benar dan runtut. Hanya saja siswa kurang teliti dalam menuliskan simbol satuan luas. Simbol satuan luas pada soal no. 1 seharusnya ditulis $\mathrm{cm}^{2}$ tetapi subjek $\mathrm{MR}_{2}$ hanya menuliskan $\mathrm{cm}$.

Pada soal no. 2 terdapat subjek belum menuliskan persamaan linear dua variabel dengan benar sehingga jawaban salah. Namun, subjek menuliskan jawaban dengan menggunakan aturan rumus dengan benar dan runtut. Ada juga subjek yang tidak menuliskan jawaban. Hanya subjek kemampuan koneksi matematis tinggi yang mempunyai kemampuan koneksi representasi dan koneksi prosedural dengan baik.

Pada soal no. 3 hanya subjek kemampuan koneksi matematis rendah yang belum mempunyai kemampuan koneksi representasi dan koneksi prosedural dengan baik. Siswa hanya menuliskan apa yang diketahui tetapi tidak lengkap. Selain itu, ada subjek yang kurang teliti dalam menuliskan jawaban padahal jawaban sudah ditulis ke dalam simbol matematikan dan dijawab 
dengan menggunakan aturan rumus yang tepat.

Siswa dikatakan mempunyai koneksi matematis ditinjau dari koneksi representasi jika siswa mampu menuliskan ungkapan dari ide-ide yang ditampilkan siswa berupa gambar, kata-kata atau teks tertulis yang mempermudah penyelesaian persamaan atau model matematika, menulis langkah-langkah penyelesaian masalah kemudian menyusun penyelesaian masalahnya dan menjawab soal dengan kata-kata atau teks tertulis untuk mempermudah menemukan solusi. Siswa dikatakan mempunyai koneksi prosedural jika dia bisa menggunakan aturan rumus yang tepat dan dikerjakan dengan runtut. Dengan kemampuan koneksi matematis siswa akan merasakan manfaat dalam mempelajari matematika, dan kemelakatan pemahaman siswa terhadap konsep yang dipelajarainya akan bertahan lebih lama [11].

Berdasarkan hasil analisis di atas, kemampuan koneksi representasi dan koneksi prosedural masih belum merata. Ada yang sudah mempunyai kemampuan koneksi representasi dengan baik dan ada yang masih rendah. Namun, hampir semua subjek sudah mempunyai kemampuan koneksi prosedural dengan baik.

\section{Penutup}

Kemampuan koneksi matematis siswa masih belum merata karena kebanyakan siswa kurang mampu menuliskan simbol matematika pada soal cerita yang disajikan. Namun, siswa terlihat dapat menggunakan rumus dengan benar karena siswa mampu menuliskan jawaban menggunakan aturan rumus dengan benar dan runtut. Faktor penyebab kemampuan koneksi representasi dan prosedural masih rendah yaitu siswa kurang teliti, kurangnya pemahaman konsep terhadap materi, dan siswa hanya menghafal rumus. Siswa kesulitan apabila diberi soal cerita. Siswa masih kesulitan membuat permisalan ke dalam simbol matematika.

\section{Referensi}

[1] Rossydha, F., "Profil Berpikir Relasional Siswa dalam Menyelesaikan Masalah pada Operasi Aljabar Ditinjau dari Kemampuan Akademiknya di Kelas VIII MTsN Karangrejo Tulungagung Tahun Ajaran 2016/2017", (2017).
[2] Mandasari, "Analisis Kemampuan Koneksi Matematika Mahasiswa Pendidikan Matematika pada Mata Kuliah Pemodelan Matematika", (2017) 123-135.

[3] Sugiman, "Kemampuan Koneksi Matematik dalam Pembelajaran Matematika", (2017).

[4] Romli, Muhammad, "Profil Koneksi Matematis Siswa Perempuan SMA dengan Kemampuan Matematis Tinggi dalam Menyelesaikan Masalah Matematika",(2017).

[5] Rismawati, dkk, "Analisis Kesalahan Koneksi Matematis Siswa pada Materi Sistem Persamaan Linier Dua Variabel”, Prosiding Universitas Muhammadiyah, (2016).

[6] Suominen, A.L., "Abstract Algebra and Secondary School Mathematics Connections as Discussed by Mathematicians and Mathematics Educators" dalam Wasserman, N.H. (Ed.), Connecting Abstract Algebra to Secondary Mathematics, for Secondary Mathematics Teachers. New York, NY, USA: Springer, (2018).

[7] Garcia-Garcia, J. \& Dolores-Flores, C., "Preuniversity students'mathematical connections when sketching the graph of derivative and antiderivative functions", Mathematics Education Research Journal, (2019).

[8] Huda, Nurul, "Profil Kemampuan Koneksi Matematika Siswa dalam Menyelesaikan Masalah Trigonometri Ditinjau Dari Kemampuan Matematika", (2018).

[9] Anandita, G.P., "Analisis Kemampuan Koneksi Matematis Siswa Smp Kelas Viii Pada Materi Kubus Dan Balok", (2015).

[10] Miles,M.B, Huberman,A.M, dan Saldana,J., "Qualitative Data Analysis, A Methods Sourcebook", Edition 3. USA: Sage Publications, Terjemahan Tjetjep Rohindi Rohidi, UI-Press, (2014).

[11] Siagian, M.D., "Kemampuan Koneksi Matematik dalam Pembelajaran Matematika", Journal of Mathematics Education and Science, 2(1), (2016) 59-67. 